\title{
GRANICA POMIĘDZY DOKUCZANIEM A PRZESTĘPSTWEM STALKINGU ORAZ INNYMI TYPAMI CZYNÓW ZABRONIONYCH
}

\section{WSTĘP}

Przestępstwo stalkingu zostało określone w art. 190a Kodeksu karnego ${ }^{1}$, zgodnie z którym karze pozbawienia wolności do lat 3 podlega ten, kto przez uporczywe nękanie innej osoby lub osoby jej najbliższej wzbudza u niej uzasadnione okolicznościami poczucie zagrożenia lub istotnie narusza jej prywatność. Co ważne, przestępstwo to zostało dodane do Kodeksu karnego na mocy nowelizacji ${ }^{2}$ z 2011 r. Tymczasem w Kodeksie wykroczeń ${ }^{3}$, już od momentu jego uchwalenia, tzn. 1971 r., funkcjonuje wykroczenie stypizowane w art. $107 \mathrm{k}$.w. potocznie określane dokuczaniem, zgodnie z którym, kto w celu dokuczenia innej osobie złośliwie wprowadza ją w błąd lub w inny sposób złośliwie niepokoi, podlega karze ograniczenia wolności, grzywny do 1500 złotych albo karze nagany. Poza zmianą przewidywanej za to wykroczenie kary, co wynika $\mathrm{z}$ denominacji złotego, treść tego przepisu na przestrzeni prawie 50 lat nie uległa żadnym zmianom ${ }^{4}$. Już na pierwszy rzut oka pomiędzy znamionami obu tych czynów zabronionych zachodzi istotne podobieństwo. Wskazać trzeba, że liczba zachowań kwalifikowanych jako stalking wzrasta, począwszy od 38 skazań w pierwszym roku funkcjonowania przepisu art. 190a k.k. do 908 przypadków skazań w roku $2014^{5}$, co powoduje także, że istotnego znaczenia zarówno w kwestii praktyki orzeczniczej, jak i od strony teoretycznej nabiera sposób, w jaki ustawodawca dokonał delimitacji znamion czynu zabronionego będącego przestępstwem od znamion wykroczenia. Jednocześnie jednak należy dodać, że możliwy zbieg w tym zakresie może także wystapić w stosunku do innych czynów zabronionych w Kodeksie karnym, cechujących się uporczywością działania i niepokojeniem pokrzywdzonego, takimi jak kierowanie gróźb karalnych czy znęcanie się.

Zasadne jest więc dokonanie bliższej analizy przepisów penalizujących wskazane zachowania, ze szczególnym uwzględnieniem tego, czy, a jeśli tak,

\footnotetext{
${ }^{1}$ Ustawa z 6 czerwca 1997 r. - Kodeks karny, Dz.U. 1997 nr 88 poz. 553 (dalej jako: k.k.).

${ }^{2}$ Ustawa z 25 lutego 2011 r. o zmianie ustawy - Kodeks karny, Dz. U. 2011, Nr 381, poz. 72.

${ }^{3}$ Ustawa z 20 maja 1971 r. - Kodeks wykroczeń, t.jedn.: Dz. U. 2018, poz. 618 (dalej jako: k.w.).

${ }^{4}$ Zob. pierwotne brzmienie przepisu: Dz. U. 1971, Nr 12, poz. 114.

${ }^{5}$ Ministerstwo Sprawiedliwości (2014): 169.
} 
to w jaki sposób, przepisy te pozostają ze sobą w jakimś stosunku oraz jaka jest pomiędzy nimi granica. Szczególnie jest to uzasadnione obserwowana ostatnio tendencją ustawodawcy do rozszerzenia stosowania norm prawa karnego na sytuacje, w których społeczna szkodliwość czynu niekoniecznie uzasadnia kwalifikowania ich jako przestępstw, a co prowadzi do marginalizacji znaczenia prawa wykroczenia. Odnieść to można również do wykroczenia określonego w art. $107 \mathrm{k}$.w. w zakresie, w jakim jest on pomijany przy ocenie kwalifikacji prawnej określonego zachowania. Z drugiej jednak strony z uwagi na postęp technologiczny i łatwość komunikacji trzeba przyznać, że i liczba czynów określanych jako stalking jest co raz większa jak i większa, jest intensywność tych działań6.

\section{WYKROCZENIE DOKUCZANIA}

Wykroczenie opisane w art. $107 \mathrm{k} . \mathrm{w}$. umiejscowione zostało w rozdziale XII k.w., zatytułowanym: „Wykroczenia przeciwko osobie”. Jego istota jest chronienie „spokoju psychicznego człowieka, przeciwdziałanie frustracji, irytacji oraz innym formom dyskomfortu psychicznego"7. Znamiona tego czynu opisane zostały w sposób bardzo ocenny, ponieważ każdy z jego elementów został sformułowany w sposób nieostry - dotyczy to zarówno celu działania, jakim jest dokuczenie, a także czynności złośliwego wprowadzenia w błąd czy złośliwego niepokojenia. Według Słownika języka polskiego dokuczać znaczy: „świadomie i celowo sprawiać komuś przykrość, ból; zaczepiać, drażnić, denerwować; utrudniać komuś życie"8. Ustawa wymaga, by dokuczanie było złośliwe, czego podkreślenie wskazuje, że ustawodawcy nie chodziło o zwykłe dokuczanie, a o taki sposób działania, który jest naganny i nieakceptowalny. W potocznym rozumieniu tego słowa, co należy wziać pod uwage przy wykładni znamion czynu zabronionego, dokuczanie jest społecznie akceptowalne, jeśli odbywa się w granicach zwyczajowo przyjętych, najczęściej w charakterze dowcipu. Dokuczaniem jest przykładowo czynienie sobie z kogoś żartów, czego ta osoba może nie akceptować, ale na swój sposób bawi to innych. Na gruncie art. 107 k.w. chodzi zatem o taki sposób zachowania, który rażąco wykracza poza społecznie akceptowalne granice. Słusznie zatem Sąd Najwyższy wskazał, że „Przypisanie obwinionej tego, że niepokoiła pokrzywdzoną "złośliwie» nie może zastapić znamienia w postaci "w celu dokuczenia«"9.

Znajduje to także uzasadnienie w treści przepisu, albowiem zdominowany jest on przez znamiona strony podmiotowej przez wyraźne podkreślenie, że sprawca ma działać złośliwie w celu dokuczenia ${ }^{10}$. Wśród znamion strony przedmiotowej ustawodawca wymienia jedynie wprowadzanie osoby w błąd

\footnotetext{
6 Siemiaszko (2010): 45-80; Mrozek, Golińska-Konecko (2015): 78.

7 Zbrojewska (2013).

8 Dunaj (1996): 184.

9 Wyrok SN z 4 września 2013 r., III KK 275/13, Lex nr 1363022.

10 Daniluk (2016): 732.
} 
lub inny sposób niepokojenia, z czego wynika, że katalog ten ma charakter otwarty, pod warunkiem jednak uznania określonego działania za złośliwe i podjęte w celu dokuczenia. Niepokojenie obejmuje różnego rodzaju zachowania sprawcy, które powodują zakłócenie spokoju psychicznego przez wywołanie u niego poczucia przykrości, zdenerwowania, wyprowadzenia z równowagi, rozdrażnienie, a desygnatami takiego zachowania mogą być, przykładowo: wykonywanie głuchych telefonów, pukanie do drzwi i uciekanie ${ }^{11}$, czyli krótko rzecz ujmując - zachowania odpowiadające wiekowi dziecięcemu, które nie przystoją dorosłemu człowiekowi. Nie realizuje znamion tego wykroczenia sytuacja, w której wierzyciel wielokrotnie puka do drzwi dłużnika, upominając się zwrot pożyczki, ponieważ w jego działaniu brak jest celu dokuczenia ${ }^{12}$. Paweł Daniluk wskazuje przy tym, że realizacji tych znamion można dopuścić się także przez zaniechanie, przykładowo w sytuacji, gdy sprawca zobowiązany do działania, np. sprzątania całego bloku, celowo powstrzymuje się od sprzątania fragmentu, gdzie zamieszkuje nielubiany przez niego pokrzywdzony, aby zrobić mu na złość, lub też w razie nieściszenia muzyki ${ }^{13}$, z czym jednak nie można się zgodzić.

W przedstawionych przykładach sprawca ponosić będzie odpowiedzialność na gruncie art. 101 k.w., art. 102 k.w. lub art. 51 § 1 k.w., lub też odpowiedzialność administracyjna czy cywilna z tytułu zawartej umowy. Zgodzić się należy, że wykroczenie to można popełnić jedynie z działania ${ }^{14}$. Co prawda katalog zachowań niepokojacych jest otwarty, ale ze wskazanego przez ustawodawcę przykładu wprowadzenia w błąd wnioskować można o tym, że realizacja czynności wykonawczej wymaga przedsięwzięcia jakichśs ruchów po stronie sprawcy. Będzie tak zarówno w odniesieniu do wprowadzenia kogoś $\mathrm{w}$ błąd, co wymaga pewnego przekazu informacyjnego, jak i innego sposobu niepokojenia, które może być realizowane powtarzalnym zachowaniem skierowaniem przeciwko spokojowi psychicznemu pokrzywdzonego.

$\mathrm{Na}$ gruncie wykroczenia z art. 107 k.w. istotna kwestia jest to czy, czy wykroczenie to ma charakter formalny, czy materialny. W doktrynie dominuje pogląd o jego bezskutkowym charakterze ${ }^{15}$. Nie można jednak tracić z pola widzenia tego, że celem ochronnym tej normy jest spokój psychiczny człowieka, wobec czego stwierdzenie realizacji znamion tego wykroczenia per se wymagać musi naruszenia jego spokoju. Złośliwe niepokojenie wymaga bowiem wzbudzenia niepokoju, obawy czy lęku ${ }^{16}$. Oczywiste jest przy tym, że wszczęcie postępowania $\mathrm{w}$ sprawie ukarania sprawcy wykroczenia wymaga inicjatywy pokrzywdzonego. Trudno jest bowiem przypuszczać, by policja w takich sprawach działała bez wcześniejszego zawiadomienia o takim czynie od osoby, która poczuła się pokrzywdzona takim zachowaniem. Mając zatem na względzie definicję wykroczenia materialnego, rozumianego jako wywołanie w świecie

\footnotetext{
11 Daniluk (2016).

12 Wyrok SN z 30 stycznia 2013 r., III KK 213/12, Lex nr 1288694.

13 Daniluk (2016): 732-733.

14 Bojarski (2012): 175.

15 Daniluk (2016): 733; Zbrojewska (2013); Mozgawa (2009).

16 Bojarski (2016): 844.
} 
zewnętrznym skutku, zmiany w następstwie czynności sprawczej wykroczenia ${ }^{17}$, wzbudzenie w pokrzywdzonym stanu niepokoju czy złości w sposób oczywisty należy postrzegać w kategoriach skutku tego wykroczenia.

\section{PRZESTĘPSTWO STALKINGU}

Jak wskazano powyżej, stalking jako przestępstwo został wprowadzony do Kodeksu karnego w 2011 r. W przeprowadzonym przed reformą przez Ministerstwo Sprawiedliwości badaniu na temat stalkingu co dziesiąty badany wskazał, że był jego ofiara, a najczęstszą jego formą było rozpowszechnienie plotek, nawiązywanie niechcianego kontaktu, groźby, szantaż, niechciane wiadomości e-mailowe i SMS-owe, głuche telefony ${ }^{18}$. W'́ród skutków takich działań badani wskazywali poważne zaburzenia psychiczne, strach, obawę wyjścia z domu, ataki paniki, a co dziewiąta osoba miała nawet myśli samobójcze $^{19}$. Projektodawca, mając na względzie wyniki przeprowadzonych badań oraz analizy zjawiska w ustawodawstwie innych krajów, wskazał, że zachowania kwalifikowane jako stalking godzą w takie wartości konstytucyjne, jak: wolność, godność i cześć, wobec czego szczególnie ważna jest ochrona pokrzywdzonego przez zapewnienie zakazu kontaktów sprawcy z pokrzywdzonym.

Czynnością wykonawczą określoną w art. 190a $§ 1$ k.k. jest uporczywe nękanie innej osoby, co może przybrać różne formy, począwszy od rozmów telefonicznych, wysyłania SMS-ów, nachodzenie, śledzenie czy narzucanie sięer Istotą uporczywości jest „szczególne nastawienie psychiczne, wyrażające się w nieustępliwości nękania, tj. trwaniu w swego rodzaju uporze, mimo próśb i upomnień pochodzących od pokrzywdzonego [...] o zaprzestanie przedmiotowych zachowań, z drugiej natomiast strony - dłuższy upływ czasu, przez który sprawca je podejmuje"21. Przy ocenie znamienia uporczywości trzeba mieć na względzie to, że okoliczność ta nie ma charakteru jednolitego i należy ją rozpatrywać w kategoriach obiektywno-subiektywnych ${ }^{22}$, ponieważ art. $190 \mathrm{a} \S 1$ k.k. posługuje się obok subiektywnego odczucia pokrzywdzonego także kryterium obiektywnym w postaci uzasadnionego okolicznościami zagrożenia. Sąd Najwyższy wskazał słusznie, że „Subiektywne odczuwanie zagrożenia przez osobę należy konfrontować z wiedza, doświadczeniem i psychologia reakcji ogółu społeczeństwa, obiektywizować przez poczucie zagrożenia w danych okolicznościach, jakie towarzyszyłoby przeciętnemu człowiekowi, o ile oczywiście działania sprawcy nie zmaterializowały się w konkretnym skutku", tym samym - jak stwierdził Sąd Najwyższy - „działania sprowadzające się do obserwacji, filmowania i fotografowania pokrzywdzonych spoza ich posesji,

\footnotetext{
17 Bojarski (2012): 60.

18 Uzasadnienie projektu ustawy, druk 3553, Sejm VI kadencji.

19 Uzasadnienie projektu ustawy, druk 3553, Sejm VI kadencji.

20 Zoll (2017): 591-592.

21 Wyrok SA we Wrocławiu z 19 lutego 2014 r., II AKa 18/14, Lex nr 1439334.

22 Staręa (2012): 194-195.
} 
zamykające się tylko w sferze prywatnego dokumentowania, nieużywane do ściąnięcia na pokrzywdzonych jakiegokolwiek wymiernego zagrożenia, nie wypełniają znamienia poczucia zagrożenia z art. 190a $\S 1 \mathrm{k} . \mathrm{k}$. Moga jednak stanowić istotne naruszenie prywatności”'23. W innym z kolei orzeczeniu Sąd Najwyższy słusznie także zauważył, że: „By zachowanie mogło być uznane za stalking, nękanie przez sprawcę musi być uporczywe, a zatem polegać na nieustannym oraz istotnym naruszaniu prywatności innej osoby oraz na wzbudzeniu w pokrzywdzonym uzasadnionego okolicznościami poczucia zagrożenia. Ustawodawca nie wymaga przy tym, aby zachowanie stalkera niosło ze sobą element agresji. Nadto prawnie irrelewantne jest w kontekście strony podmiotowej tego przestępstwa, czy czyn sprawcy powodowany jest żywionym do pokrzywdzonego uczuciem miłości, nienawiści, chęcią dokuczenia mu, złośliwością czy chęcią zemsty"24. Wskazuje się także, że uporczywość działania ma charakter podmiotowo-przedmiotowy oznaczający wielokrotność nacechowanego negatywnie zachowania na przestrzeni określonego czasu ${ }^{25}$. Ustawodawca wyraźnie określa, że przestępstwo stalkingu ma charakter skutkowy, albowiem do jego dokonania konieczne jest, aby działanie sprawcy przyniosło skutek w postaci poczucia zagrożenia lub naruszenia prywatności. Przy ocenie, czy zachodzi taka uzasadniona okoliczność, należy dokonać analizy, czy przeciętny człowiek o porównywalnych cechach co pokrzywdzony $\mathrm{w}$ analogicznych warunkach zareagowałby w ten sam sposób ${ }^{26}$. Alternatywnie zaś sformułowany skutek w postaci istotnego naruszenia prywatności ma charakter obiektywny, ponieważ jest niezależny od odczuć pokrzywdzonego, co obejmuje dwa aspekty, a mianowicie: decydowanie o swoim wizerunku i swoim postępowaniu ${ }^{27}$.

Podobnie jak w przypadku wykroczenia z art. 107 k.w., watpliwości w doktrynie budzi to, czy przestępstwa stalkingu można dopuścić się z zaniechania. Pogląd taki wyraził Marek Mozgawa, jednakże nie rozwiną on tej myśli² Paulina Furman podaje, że „można sobie wyobrazić sytuację nękania kogoś poprzez wynikające ze złej woli utrzymywanie jakiegoś stanu bezprawnego, który wywołuje u pokrzywdzonego uczucie zagrożenia, bądź narusza jego prawo do prywatności poprzez zaniechanie usunięcia go" ${ }^{29}$. Jest to jednak pogląd odosobniony, którego krytykę należy podzielić. Słuszne jest w tym względzie stanowisko Andrzeja Zolla, że trudno z perspektywy skutku tego przestępstwa w postaci poczucia zagrożenia lub naruszenia prywatności określić sprawcę mianem gwaranta nienastapienia skutku, na którym miałby ciążyć szczególny prawny tego obowiązek ${ }^{30}$.

\footnotetext{
${ }^{23}$ Wyrok SN z 29 marca 2017 r., IV KK 413/16, Lex nr 2281268.

${ }^{24}$ Postanowienie SN z 12 grudnia 2013 r, III KK 417/13, Lex nr 1415121.

25 Królikowski, Sakowicz (2017): 588.

26 Królikowski, Sakowicz (2017): 589.

27 Mozgawa (2016): 465.

28 Mozgawa (2018).

29 Furman (2012): 44.

30 Zoll (2017): 592.
} 


\section{KWESTIA RELACJI POMIĘDZY DOKUCZANIEM A STALKINGIEM}

Kwestia stosunku, w jakim pozostają do siebie wykroczenie z art. 107 k.w. i przestępstwa $z$ art. $190 \mathrm{a} \S 1$ k.k., była już podnoszona w doktrynie i orzecznictwie, jednakże rozważania w tym zakresie były zazwyczaj ograniczone in concreto do określonego stanu faktycznego. Należy nadmienić, że w omawianym zakresie brak literatury przedmiotu, która odnosiłaby się w sposób bardziej szczegółowy do tej kwestii. Tymczasem ma to zasadnicze znaczenie z punktu widzenia tego, czy dane zachowanie określić należy jako wykroczenie, przestępstwo, czy też może zarówno jako wykroczenie, jak i przestępstwo. Skoro bowiem ustawodawca zdecydował się na wprowadzenie do Kodeksu karnego odrębnego typu czynu zabronionego stalkingu, to uznał, że dotychczasowe uregulowania w tej kwestii były niewystarczające, niemniej pozostawił wśród wykroczeń czyn opisany w art. 107 k.w. Z drugiej jednak strony w doktrynie wskazywane jest bardzo szerokie ujęcie stalkingu odnoszace się do przemocy emocjonalnej i w zasadzie jakiejkolwiek ingerencji w psychikę człowieka, przy czym panuje zgoda co do tego, że niemożliwe jest wskazanie zamkniętego katalogu zachowań będących desygnatami stalkingu ${ }^{31}$. W uzasadnieniu projektu ustawy w odniesieniu do tego zagadnienia wskazano, że: „osoby podejmujace działania, które moga być ocenione w ramach zjawiska stalkingu, niejednokrotnie wykazuja zamiary zgoła odmienne [od złośliwego celu dokuczenia w przypadku wykroczenia - J.K.], np. chęć okazania adoracji, admiracji, czy wręcz »miłości«, oczywiście bez uwzględnienia rzeczywistych emocji, czy odczuć pokrzywdzonych”, a także, że: „Tylko ewentualnie w ramach drugiego z tych znamion moglibyśmy mówić o podjęciu działań charakterystycznych dla zjawiska określanego, jako stalking, przy czym jednak należy zauważyć, że wykroczenie $\mathrm{w}$ tej postaci ma charakter formalny i jego realizacja nie jest uzależniona od wystapienia jakiegokolwiek skutku, czyli faktycznego wprowadzenia w błąd lub wzbudzenia u pokrzywdzonego uczucia niepokoju. Podkreślenia także wymaga fakt, że działanie sprawcy, który złośliwie niepokoi inną osobę może mieć charakter jednorazowy, gdy tymczasem z reguły działania podejmowane $\mathrm{w}$ ramach zjawiska stalkingu sa z reguły kilkukrotne lub wielokrotne".

$\mathrm{Na}$ gruncie styku dokuczania i stalkingu powstaje pytanie, czy możliwe jest, aby czyn sprawcy realizował zarówno znamiona wykroczenia i przestępstwa na zasadzie zbiegu idealnego z art. $10 \S 1 \mathrm{k} . \mathrm{w}$. Zoll pisze, że dokuczanie obejmuje wiele zdarzeń z zakresu przestępstwa z art. 190a, jednak jego znamiona sa zbyt waskie w stosunku do społecznych potrzeb penalizacji ${ }^{32}$. Michał Królikowski i Andrzej Sakowicz zaś zwracają uwagę na to, że możliwy jest jednoczynowy zbieg wykroczenia i przestępstwa, gdy czyn polega na uporczywym złośliwym niepokojeni osoby, które wywołuje u niej poczucie zagrożenia albo

\footnotetext{
31 Teleszewska (2014): 175-176.

32 Zoll (2017): 590.
} 
istotnie narusza prywatnośćc ${ }^{33}$. Mozgawa zwraca z kolei uwagę, że w sytuacji, w której działanie sprawcy realizuje znamiona wykroczenia, ale nie wzbudza ono poczucia zagrożenia u pokrzywdzonego, możliwe jest rozważenie kwestii odpowiedzialności za usiłowanie stalkingu, gdy taki był zamiar sprawcy ${ }^{34}$. Daniluk z kolei zauważa, że mimo istotnych odmienności zachodzących między znamionami opisanymi w art. 190a § 1 k.k. i w art. 107 k.w., może zachodzić w pewnych sytuacjach realizacja znamion czynów zabronionych, która jednak stanowi zbieg pomijalny na zasadzie lex consumens derogat legi consumptae ${ }^{35}$. Powyższe uwagi prowadzą do wniosku, że dominującym poglądem w tej kwestii jest pogląd dotyczący konsumpcji zachowań stanowiących dokuczanie przez przestępstwo stalkingu, z którym należy się zgodzić.

Skoro zatem stalking „konsumuje” dokuczanie, to pomiędzy tymi czynami zabronionymi zachodzić musi stosunek zawierania. W wyniku tego pomiędzy przestępstwem z art. 190a $\S 1$ k.k. a wykroczeniem z art. 107 k.w. zachodzi zbieg pomijalny, który wykluczać będzie jednoczesne pociagnięcie do odpowiedzialności za wykroczenie i przestępstwo. Jedynie Królikowski dopuszcza możliwość jednoczynowego zbiegu obu tych przepisów, z czym jednak nie można się zgodzić z uwagi na zrealizowanie przez znamiona art. 190a $§ 1$ k.k. skutków dalej idących w stosunku do wykroczenia. Istotą bowiem stalkingu w takich stanach faktycznych jest to, że cechuje się on wyższym stopniem kryminalnej bezprawności w stosunku do wykroczenia, co, jak podnosi słusznie Zoll ${ }^{36}$, uzasadnia „skonsumowanie” znamion jednego czynu przez drugi. Jak jednak wskazał Sąd Najwyższy: „Idealny zbieg przestępstwa z wykroczeniem, o którym mowa w art. $10 \S 1$ k.w., zachodzi wówczas gdy jakiś element, określający zabronione zachowanie, nie należy do znamion dokonanego przestępstwa, przez co jakby wykracza poza znamiona tego przestępstwa, a przy tym element ten jest karalny jako wykroczenie. Wówczas element ten nie może być pochłonięty przez znamiona odnośnego przestępstwa właśnie z tej przyczyny, że do znamion tych w ogóle nie należy" ${ }^{\prime 3}$. W odniesieniu do możliwego zbiegu dokuczania ze stalkingiem kwestia ta wymaga wyjaśnienia ze względu na możliwe pokrywania się wspólnych znamion.

Będzie tak jednak tylko wtedy, gdy skutek w postaci wzbudzenia zagrożenia lub istotnego naruszenia prywatności spowodowany został dokuczaniem. Niewątpliwe jest, że w takim przypadku sprawca musi działać nie tylko z zamiarem bezpośrednim dokuczenia, ale musi mieć świadomość konieczności tego, że jego zachowanie może wzbudzić obawę u pokrzywdzonego lub istotnie naruszyć jego prywatność i tego chcieć. W takim przypadku dokuczanie będzie stanowić formę popełnienia stalkingu. Nie będzie to jednak uzasadniać idealnego zbiegu wykroczenia z przestępstwem, ponieważ brak jest tutaj sytuacji, o jakiej mowa powyżej, a mianowicie żaden z elementów czynu stanowiącego stalking nie wykracza poza znamiona czynu opisanego w art. 190a § 1 k.k.

\footnotetext{
${ }^{33}$ Królikowski, Sakowicz (2017): 593.

${ }^{34}$ Mozgawa (2016): 464.

35 Daniluk (2016): 734.

36 Zoll (2013): 288.

37 Wyrok SN z 18 maja 2017 r., IV KK 447/16, Lex nr 2306382.
} 
Dokuczanie w tym przypadku stanowi bowiem czynność wykonawczą będąca jednocześnie uporczywym nękaniem. W tym właśnie względzie istotne jest, jaka jest granica pomiędzy jednym czynem zabronionym a drugim. Możliwe są bowiem takie sytuacje, w których sprawca, chcąc zrealizować znamiona z art. 190a $§ 1$ k.k., tego nie czyni, ponieważ obiektywnie jego zachowanie nie może wzbudzić zagrożenia. Przy analizie tego zjawiska istotną wskazówkę stanowi przywołane powyżej orzecznictwo dotyczące stalkingu. Zwraca się w nim przede wszystkim uwagę na długotrwałość zachowania sprawcy oraz sposób działania. Co oczywiste, im jest ono bardziej rozciagnięte w czasie i głębiej ingeruje w prywatność pokrzywdzonego, stanowić będzie ono o realizacji stalkingu, a nie dokuczania. Nie jest jednak wykluczone, że o odmiennej ocenie danego zachowania decydować będzie podatność pokrzywdzonego na poczucie zagrożenia, przy czym przy ocenie tego znamienia należy wziąć pod uwage zarówno względy osobiste, jak i kryteria obiektywne ${ }^{38}$. W opinii do projektu ustawy Mozgawa zwraca także uwagę, że kryterium różnicujacym stalking od dokuczania będzie także motywacja sprawcy, ponieważ „można rozważać zastosowanie art. 107 przy zrachowaniach sprawcy prześladującego swoją ofiarę z powodu zemsty, niechęci czy wręcz nienawiści, to nie będzie takiej możliwości, w przypadku gdy sprawca motywowany był np. głębokim (choć być może patologicznym i nieodwzajemnionym) uczuciem do ofiary" 39 . Również gdy działanie sprawcy jest ewidentnie skierowane na dokuczenie pokrzywdzonemu i sprawca nie przewiduje, że jego działanie może doprowadzić do istotnego naruszenia prywatności i się na to nie godzi, przypisanie stalkingu w takim przypadku jest niemożliwe ${ }^{40}$. Ustawodawca wprost w znamionach art. $190 § 1$ k.k. wymienia „nękanie”, które rozumiane jest jako „ustawiczne dręczenie, trapienie, niepokojenie (czymś) kogoś; dokuczanie komuś, nie dawanie chwili spokoju" ${ }^{41}$.

W ślad za Dagmarą Woźniakowską-Fajst trzeba także zwrócić uwagę na angielskojęzyczny rodowód potocznego określenia przestępstwa z art. 190a $\S 1$ k.k., czyli określenia „stalking” pochodzącego od czasownika stalk, oznaczajacego: „ciche tropienie człowieka lub zwierzęcia w celu schwytania go lub zabicia” ${ }^{42}$. W angielskiej terminologii prawniczej stalking definiuje się jako: „powtarzające się nękanie bez uzasadnionego powodu z zamiarem zaszkodzenia lub wzbudzenia niepokoju” 43 lub ,śledzenie ukradkiem w celu denerwowania lub zagrożenia osoby" ${ }^{44}$. Wskazane definicje mają charakter zdecydowanie węższy od polskiego uregulowania tego przestępstwa, które składa się dwóch pojęć nieostrych „uporczywości” i „nękania”, przy czym to ten drugi element definicji stanowi czynność wykonawczą czynu wskazującą na sposób działania spraw-

\footnotetext{
38 Szęlegiewicz (2013): 67-68.

39 Mozgawa (2010): 4.

40 Szczucki (2013): 25.

41 Dubisz (2003): 1095.

${ }^{42}$ Woźniakowska-Fajst (2009b): 175; Longman Dictionary of Contemporary English (1995):

43 Wild (2006): 243.

${ }^{44}$ Garner (2004): 1440.
} 1395. 
cy. Przesądza to o tym, że stalking stanowi kwalifikowaną formę dokuczenia, przynajmniej w jednej z jego postaci, ponieważ nękanie można popełnić nie tylko przez dokuczenie. Woźniakowska-Fajst, jeszcze przed uchwaleniem nowelizacji z 2011 r., wskazywała, że przepis art. 107 k.w. mógłby mieć zastosowanie do ,indyferentnych” prawnie form działania stalkera, które mają nieco inny cel od klasycznie pojmowanego stalkingu ${ }^{45}$. Postrzega zatem dokuczanie jako łagodną formę stalkingu, z czym można się zgodzić, pod takim jednak warunkiem, że może tu być mowa jedynie o stalkingu w szerokim znaczeniu, oderwanym od rozumienia kodeksowego. Wyprowadzić z tego można wniosek, że w polskim porządku prawnym zachowania odpowiadajace stalkingowi rozbite zostały na dwa czyny zabronione w ramach swoistej kategorii czynów przepołowionych, przy czym wartościa, jaka legła u podstaw tego podziału, jest intensywność działania sprawcy i skala skutków tym wywołanych. Warto jest zwrócić uwagę na to, że przykładowo w ustawodawstwie niemieckim zostało wskazane wyraźnie, od kiedy zachowanie sprawcy jest karalne, albowiem niemiecki kodeks karny przewiduje, że zachowanie to musi trwać co najmniej 1 miesiąc i składać się na nie musi co najmniej 10 zachowań sprawcy ${ }^{46}$.

$\mathrm{W}$ praktyce, na co należy zwrócić uwagę, przypadki realizacji znamion dokuczania i uporczywego nękania mogą być tożsame. Często są to bowiem niechciane SMS-y, telefony. W takim przypadku niewątpliwie oprócz kwestii okresu i skutku w postaci zagrożenia lub naruszenia prywatności, zasadnicze znaczenie będzie mieć treść tych wiadomości. O ile w przypadku stalkingu, szczególnie z biegiem czasu, wiadomości czy inna forma kontaktu stosunkowo łagodna przybiera postać agresywną z częstym formułowaniem gróźb, zarzutów czy obelg, o tyle w odniesieniu do dokuczania takie sytuacje się nie zdarzaja. Generalnie rzecz zatem ujmując, można powiedzieć, że pomiędzy wykroczeniem z art. $107 \mathrm{k} . \mathrm{w}$. a przestępstwem z art. $190 \S 1$ k.k. zachodzi stosunek krzyżowania, ponieważ znamiona obu tych czynów w pewnym zakresie moga zostać popełnione w ten sam sposób. W tym wspólnym obszarze stalking stanowi kwalifikowaną formę dokuczania i konsumuje on realizację wykroczenia na zasadzie zbiegu pomijalnego, bez potrzeby odwoływania się do konstrukcji $\mathrm{z}$ art. $10 \S 1 \mathrm{k}$.w. Nie można pomijać tego, że art. $107 \mathrm{k}$.w. posługuje się także znamieniem wprowadzenia w błąd, które nie może być postrzegane w kategoriach stalkingu, natomiast nie wszystkie formy uporczywego nękania będa stanowiły złośliwe niepokojenie, jak chociażby rozpowszechniane na temat pokrzywdzonego wśród innych osób oszczerstwa.

\section{DOKUCZANIE A INNE TYPY CZYNÓW ZABRONIONYCH}

Na gruncie Kodeksu karnego zachowania realizujace znamiona wykroczenie z art. $107 \mathrm{k} . \mathrm{w}$. stanowić także mogą desygnaty innych niż stalking czynów zabronionych. Zauważyć przy tym należy, że do czasu wejścia w życie

45 Woźniakowska-Fajst (2009a): 28-29.

46 Zob. Woźniakowska-Fajst (2013): 195. 
przestępstwa stalkingu w 2011 r. zachowania określane tym mianem rozpatrywane były głównie w kategoriach przestępstwa znęcania się ${ }^{47}$. Trzeba jednak mieć na względzie, to że znęcanie się może zostać popełnione jedynie w stosunku do osoby najbliższej lub pozostającej w stałym lub przemijającym stosunku zależności od sprawcy (art. $207 \S 1$ k.k.) albo w stosunku do osoby nieporadnej ze względu na wiek, stan psychiczny lub fizyczny (art. 207 $\S 1 \mathrm{a}$ k.k.). W odniesieniu do możliwego zbiegu znęcania się z dokuczaniem, zasadnicze znaczenie będzie mieć forma psychicznego znęcania się. Istota tego przestępstwa jest „systematycznie powtarzające się zachowania złożone z jedno- lub wielorodzajowych pojedynczych czynności naruszających różne dobra, np. nietykalność ciała, godność osobista" ${ }^{48}$. Znęcanie psychiczne stanowić będzie dręczenie psychiczne, np. przez lżenie, wyszydzanie, straszenie, poniżanie, które związane jest z zadawaniem pokrzywdzonemu dotkliwego bólu psychicznego ${ }^{49}$. Prima facie brak w takiej czynności wykonawczej elementów dokuczania, oba te czyny zabronione skierowane są jednak przeciwko spokojowi psychicznemu pokrzywdzonego. Szczególny wyraz temu dał Sąd Najwyższy w postanowieniu z 23 sierpnia 2017 r., w którym stwierdził, że: „sprowadzanie do wspólnego domu obcych kobiet, pozostających tam w godzinach nocnych, można uznać za formę szczególnego dokuczania żonie i córkom" ${ }^{0}$. Nie wchodząc w szczegóły stanu faktycznego leżącego u podstaw rozstrzygnięcia w tej sprawie, dodać należy, iż Sąd trafnie wyartykułował w uzasadnieniu swojego stanowiska, że takie działanie sprawcy „można uznać za formę szczególnego dokuczania pokrzywdzonym”. W konsekwencji wyprowadzić można z tego wniosek, że dokuczanie, a właściwie złośliwe niepokojenie, może stanowić desygnat znęcania się psychicznego, jeśli wiąże się ze szczególnym udręczeniem pokrzywdzonego, cechuje się dużo większą intensywnościa działania, a przy tym sprawca działa nie tylko w celu dokuczenia, ale także co najmniej godząc się na wywołanie u pokrzywdzonego bólu psychicznego, poniżenia czy wyrządzenia mu krzywdy.

Odnotowania wymaga także pogląd wyrażony przez Marka Bojarskiego ${ }^{51}$ przywołuje on wyrok Sądu Rejonowego w Rudzie Ślasskiej, który stwierdził, że: „Wypowiedzi takie jak "pilnuj lepiej swoich bachorów», "wstaw sobie kraty w oknach domu«, "wsadzę cię szybko do więzienia», »ja ci pokażę, załatwię cię«, czy »zrzucę cię ze stołka», nie wyrażają nic konkretnego, stanowią groźbę niedookreśloną i można je ocenić wyłącznie jako niepokojenie, co implikuje przyjęcie kwalifikacji z art. 107 Kodeksu wykroczeń. U̇̇ycie powyższych sformułowań zmierzało niewątpliwie do dokuczenia pokrzywdzonej, a zachowanie oskarżonego miało charakter złośliwy"52. Stanowisko to prowadzi do wniosku, że możliwy jest także zbieg wykroczenia z art. 107 k.w. z przestępstwem gróźb karalnych z art. 190a $\S 1$ k.k. w sytuacji, kiedy wykroczenie popełnione jest

\footnotetext{
${ }^{47}$ Kosińska (2008): 37-39.

48 Jodłowski, Szewczyk (2017): 861.

49 Jodłowski, Szewczyk (2017): 861.

50 Postanowienie SN z 2 sierpnia 2017 r., II KK 133/17, Lex nr 2342157.

51 Bojarski (2016): 843.

${ }^{52}$ Wyrok SR w Środzie Śląskiej z 17 grudnia 2013 r., II K 84/13, Legalis nr 924725.
} 
w formie kierowania gróźb karalnych. Wydaje się, że granica pomiędzy wykroczeniem a przestępstwem będzie realność tych gróźb oraz ich intensywność. Za istotę wykroczenia przyjaćc należy w takim przypadku bezpodstawność tych gróźb, które nie mogą wzbudzić uzasadnionego poczucia zagrożenia oraz które wypowiedziane zostały więcej niż jeden raz. Jeśli bowiem byłoby to zdarzenie całkowicie jednostkowo, trudno byłoby mówić o jakimś zakłóceniu spokoju psychicznego pokrzywdzonego.

\section{ZAKOŃCZENIE}

Reasumując powyższe rozważania, można sformułować wniosek, że działanie realizujace znamiona wykroczenia z art. 107 k.w. stanowić mogą desygnaty również zachowań przestępczych z Kodeksu karnego, w szczególności stalkingu (art. 190a § 1 k.k.), ale także znęcania się (art. $207 \S 1$ k.k.). Nie jest przy tym wykluczone, że również na gruncie innych przestępstw może dojść do konsumpcji znamion wykroczenia dokuczania na rzecz znamion przestępstwa. Mając to na względzie, należy przyjaćc, że przede wszystkim dla ustalenia, czy dane zachowanie należy kwalifikować jako wykroczenie, czy też przestępstwo, niezbędne jest określenie tego, czy realizuje ono także inne znamiona przestępstwa poza czynnością wykonawcza, o ile dla przyjęcia danego czynu zabronionego konieczne jest także zrealizowanie innych znamion. Związana jest z tym kolejna kwestia, albowiem konieczne jest ustalenie stopnia intensywności oddziaływania sprawcy na spokój psychiczny pokrzywdzonego, w szczególności to, czy oprócz działania złośliwego sprawca powoduje swoim zachowaniem udręczenie pokrzywdzonego lub inną kwalifikowaną formę dolegliwości psychicznych.

Generalnie należy przyjąć, że przestępstwo stalkingu stanowić będzie kwalifikowaną formę dokuczania, jeśli złośliwemu działaniu sprawcy towarzyszyć będzie naruszenie prywatności pokrzywdzonego lub wywołanie u niego odczucia lęku. Nie każda jednak czynność wykonawcza dokuczania pokrywać się będzie ze znamieniem czasownikowym przestępstwa stalkingu, wobec czego przyjąć należy, że pomiędzy znamionami obu tych czynów zabronionych zachodzić będzie stosunek krzyżowania się, albowiem w stosunkowo szerokim zakresie realizacja znamion wykroczenia stanowić może jednocześnie desygnaty przestępstwa z art. 190a $§ 1$ k.k. W odniesieniu zaś do przestępstwa znęcania się ten zakres również się krzyżuje, niemniej ze względu na odmienny cel ochronny tego przestępstwo zakres ten wydaje się zdecydowanie mniejszy. W przypadku innych możliwych zbiegów tego wykroczenia z przestępstwami zakres ten w jeszcze większym stopniu będzie malał.

Jan Kluza

Uniwersytet Jagielloński w Krakowie

jan.kluza@student.uj.edu.pl

https://orcid.org/0000-0002-0929-6093 
Bojarski, M. (2016). Komentarz do art. 107 k.w., [w:] M. Bojarski, W. Radecki, Kodeks wykroczeń. Komentarz. Warszawa: 842-845.

Bojarski, T. (2012). Polskie prawo wykroczeń. Zarys wykładu. Warszawa.

Daniluk, P. (2016). Komentarz do art. 107 k.w., [w:] P. Daniluk (red.), Kodeks wykroczeń. Komentarz. Warszawa: 731-734.

Dubisz, S. (red.) (2003). Uniwersalny słownik języka polskiego. Tom 2. Warszawa.

Dunaj, B. (red.) (1996). Słownik współczesnego języka polskiego. Warszawa.

Furman, P. (2012). Próba analizy konstrukcji ustawowej przestępstwa uporczywego nękania z art. 190a k.k. Zagadnienia wybrane. Czasopismo Prawa Karnego i Nauk Penalnych 3: $43-78$.

Garner, B.A. (2004). Black's Law Dictionary. West.

Jodłowski, J., Szewczyk, M. (2017). Komentarz do art. 207 k.k., [w:] W. Wróbel, A. Zoll, Kodeks karny. Część szczególna. Tom 2, Część 1: Komentarz do art. 117-211a. Warszawa: 852-881.

Kosińska, J. (2008). Prawnokarna problematyka stalkingu. Prokuratura i Prawo 10: 33-47.

Królikowski, M., Sakowicz, A. (2017). Komentarz do art. 190a k.k., [w:] M. Królikowski, R. Zawłocki (red.), Kodeks karny. Część szczególna. Tom 1: Komentarz art. 117-221. Warszawa: $583-594$.

Longman Dictionary of Contemporary English (1995), Longman Group Ltd.

Ministerstwo Sprawiedliwości (2014). Prawomocne skazania osób dorosłych w latach 1946-2014. Warszawa.

Mozgawa, M. (2010). Opinia w sprawie projektu ustawy o zmianie ustawy - Kodeks karny (druk sejmowy nr 3553).

Mozgawa, M. (2018). Komentarz do art. 190a k.k., [w:] M. Mozgawa (red.). Kodeks karny. Komentarz aktualizowany. Lex/el.

Mozgawa, M. (2010). Komentarz do art. 107 k.w., [w:] M. Mozgawa (red.). Kodeks wykroczeń. Komentarz. Lex/el.

Mozgawa, M. (2016). Przestępstwa stalkingu (nękania) i podszywania się (art. 190a k.k.), [w:] J. Warylewski (red.), System prawa karnego. Tom 10: Przestępstwa przeciwko dobrom indywidualnym. Warszawa: 450-480.

Mrozek, J., Golińska-Konecko, M. (2015). Przestępstwo stalkingu wobec osób powszechnie znanych. Media - Kultura - Komunikacja Społeczna 11(2): 73-83.

Siemiaszko, A. (red.) (2010). Stalking w Polsce. Rozmiary - formy - skutki. Raport z badania nt. uporczywego nękania. Archiwum Kryminologii 32: 45-80.

Staręga, M. (2012). Stalking jako nowy czyn zabroniony w polskim kodeksie karnym. Aspekt prawny oraz znaczenie społeczne. Zeszyty Naukowe Uniwersytetu Przyrodniczo-Humanistycznego w Siedlcach. Seria: Administracja i Zarządzanie 94: 191-201.

Szczucki, K. (2013). Wykładnia prokonstytucyjna w praktyce. Przykład stalkingu. Forum Prawnicze 6: 18-28.

Szęlegiewicz, A. (2013). Stalking i przywłaszczenie tożsamości w polskim prawie karnym - zagadnienia wybrane. Ius Novum 3: 63-85.

Teleszewska, M. (2014). Pojęcie przestępstwa stalkingu (uporczywego nękania). Zeszyty Naukowe Uniwersytetu Rzeszowskiego. Seria Prawnicza 84: 172-180.

Wild, S.E. (2006). Webster's New World. Law Dictionary. Hoboken.

Woźniakowska-Fajst, D. (2009a). Prawne możliwości walki ze zjawiskiem stalkingu. Analiza regulacji prawnych w ustawodawstwach państw obcych oraz opinia o wprowadzeniu do polskiego porządku prawnego przepisów kryminalizujących to stanowisko. Warszawa 2009.

Woźniakowska-Fajst, D. (2009b). Prawne możliwości walki ze zjawiskiem stalkingu - czy w prawie polskim potrzebna jest penalizacja prześladowania. Archiwum Kryminologii 31: 173-208.

Woźniakowska-Fajst, D. (2013). Stalking w prawie polskim i unijnym, [w:] J. Utrat-Milecki, Reformy prawa karnego. W stronę spójności i skuteczności. Warszawa: 192-202.

Zbrojewska, M. (2013). Komentarz do art. 107 k.w., [w:] T. Grzegorczyk (red.), Kodeks wykroczeń. Komentarz. Lex/el.

Zoll, A. (2013). Zbieg przepisów ustawy w polskim prawie karnym. Annales Universitatis Mariae Curie-Skłodowska Lublin-Polonia. Sectio G 60(2): 281-295.

Zoll, A. (2017). Komentarz do art. 190a k.k., [w:] W. Wróbel, A. Zoll, Kodeks karny. Część szczególna. Tom 2, Część 1: Komentarz do art. 117-211a. Warszawa: 589-597. 


\section{THE BORDERLINE BETWEEN BULLYING AND STALKING, AND OTHER TYPES OF OFFENCES}

\section{Sum mary}

The article presents issues associated with determining the relationship between the offences specified in Article 107 of the Code of Misdemeanors and the crime of stalking from Article 190a $\S 1$ of the Penal Code, and other types of crimes characterized by the violation of the mental peace of the victim. These acts intersect each other, and the borderline between them is determined primarily by the intensity of the perpetrator's actions.

Keywords: harassment; malice; stalking; bullying 
